\title{
A hyperthyreosis kezelésének ritka mellékhatásai
}

\author{
Sohár Gábor dr. - Kovács Mónika dr. \\ Györkös Andrea dr. - Gasztonyi Beáta dr. \\ Zala Megyei Kórház, Belgyógyászati Osztály, Zalaegerszeg
}

\begin{abstract}
A szerzók hyperthyreosis miatt gondozott beteg esetét ismertetik, akinél a kezelés során propiltiouracil indukálta vasculitis igazolódott renalis érintettséggel, amely a gyógyszerelhagyást követően, illetve kortikoszteroidterápia mellett rendeződött. Ezt követően tiamazolkezelés során agranulocytosis alakult ki lázas állapottal. A vérképeltérések normalizálódása után átmeneti lítium-karbonát terápiát követően a hyperthyreosis sikeres mútéti megoldására került sor. A hyperthyreosis kezelésében alkalmazott gyógyszerek ilyen súlyos mellékhatásainak halmozott előfordulása ritka, amely jól mutatja, hogy ezen gyakori kórkép kezelése is tartogat kihívásokat a klinikus számára. Orv. Hetil., 2016, $157(22), 869-872$.
\end{abstract}

Kulcsszavak: hyperthyreosis, vasculitis, agranulocytosis

\section{Rare side effects in management of hyperthyroidism}

\section{Case report}

The authors present the case history of a patient suffering from hyperthyroidism. The diagnostic procedures revealed the presence of propylthiouracyl induced vasculitis with renal involvement, that recovered completely after the withdrawal of propylthiouracyl and corticosteroid treatment. Thereafter, the patient was treated with thiamasol, that caused agranulocytosis with fever. After transient litium carbonate therapy a succesful thyreoidectomy was performed. Cumulative serious side effects of antithyroid drugs are rare. This case highlights some of the challenges and complications encountered in the management of hyperthyroidism.

Keywords: hyperthyreosis, vasculitis, agranulocytosis

Sohár, G., Kovács, M., Györkös, A., Gasztonyi, B. [Rare side effects in management of hyperthyroidism. Case report]. Orv. Hetil., 2016, 157(22), 869-872.

(Beérkezett: 2016. március 6.; elfogadva: 2016. március 27.)

\section{Rövidítések}

ANCA = antineutrophil citoplazmatikus ellenanyag; GFR = glumerulusfiltrációs ráta; $\mathrm{MPO}=$ mieloperoxidáz; PTU = propiltiouracil; TRAK $=$ TSH-receptor elleni antitest; $\mathrm{TSH}=$ thyreoideastimuláló hormon

A hyperthyreosis kezelésére alkalmazott tionamidokkal végzett terápia során $3-5$ ezrelékes gyakorisággal agranulocytosis alakul ki [1], ezért a fehérvérsejtszámot kezdetben kéthetente, majd havonta ellenőrizni szükséges. A betegek figyelmét célszerú felhívni, hogy láz, illetve torokpanaszok együttes jelentkezése esetén haladéktalanul vérképvizsgálatot kell végeztetni. Lázzal járó agranulocytosis esetén intézeti felvétel, széles spektrumú antibiotikus kezelés indítása és szükség esetén kolóniastimuláló faktor alkalmazása javasolt. A vérkép rendeződését követôen a tiamazol és a propiltiouracil (PTU) sem alkalmazható, átmenetileg lítium-karbonát kezelés választható, és a hyperthyreosis mielőbbi definitív megoldására kell törekedni (mûtéti vagy radiojódkezelés).

Egyes vasculitissel járó betegségekben antineutrophil citoplazmatikus ellenanyag (ANCA) mutatható ki. A PTU ismerten okozhat ANCA-pozitivitást, habár ezen bete- 
gek csak kis részében alakul ki vasculitis [2]. A szerzók tudomása szerint eddig 260 esetben került leírásra a nemzetközi irodalomban PTU által kiváltott vasculitis [2].

$\mathrm{Az}$ alább ismertetett, hyperthyreosis miatt gondozott betegnél propiltiouracil indukálta vasculitis alakult ki, majd terápiaváltást követően tiamazolkezelés mellett agranulocytosis jelentkezett.

\section{Esetismertetés}

A 43 éves nőbeteg kórelőzményében ismert laktózintolerancia, két alkalommal sectio cesarea szerepelt. Gyógyszert rendszeresen nem szedett, 2011 januárjában szült. Endokrinológiai szakrendelésünkön fogyás, izzadékonyság, szapora szívverés panaszával 2012 októberében jelentkezett. Fizikális vizsgálattal tachycardiát, göbösen megnagyobbodott pajzsmirigyet észleltünk. Laborleletei manifeszt hyperthyreosist mutattak (TSH: 0,005 mU/1, normális tartomány: 0,4-3,2 mU/1; $\mathrm{FT}_{4}: 46,30 \mathrm{pmol} / \mathrm{l}$, normális tartomány: $9,1-23,8 \mathrm{pmol} / 1 ; \mathrm{FT}_{3}: 28,97$ pmol/1, normális tartomány: 2,2-6,5 pmol/l). A nyaki ultrahang jobb oldali túlsúllyal megnagyobbodott pajzsmirigylebenyeket mutatott kétoldali echódús, cystosus göbökkel (jobb lebeny alsó pólusában $4 \mathrm{~cm}$-es átmérőjü göbös terület, bal lebenyben több $1 \mathrm{~cm}$-es göb). Az alapszerkezet és a göbök környezete is kifejezetten hypervascularizált volt. Panaszai miatt hyperthyreosisára $3 \times 50 \mathrm{mg}$ PTU, $2 \times 40 \mathrm{mg}$ propranololkezelést kezdtünk, tiamazol a szoptatás miatt egyelőre nem jött szóba. A hyperthyreosis, struma nodosa miatt tervezett pajzsmirigy-szcintigráfia elvégzését a szoptatásra tekintettel szintén prolongáltuk. A klinikai kép és a jelentősen emelkedett TSH-receptor-antitest- (TRAK-) érték (TRAK: 40,00 IU $/ 1$, normális tartomány <1,5 IU/1) alapján Graves-Basedow-kórt igazoltunk. A betegnek endokrin orbitopathiára utaló tünete nem volt. Jelentős méretú struma miatt (jobb lebeny $30 \mathrm{ml}$, bal lebeny $13 \mathrm{ml}$ térfogatú volt) nyelési röntgenvizsgálatot is végeztettünk, amely nyelőcső- és trachealégsáv-dislocatiót mutatott a mellkasbemenet szintjében, amely a trachea 30 százalékot el nem érő, mérsékelt szúkületével járt jobb oldal felől. A szoptatás befejezését követően javasolt pajzsmirigy-szcintigráfiát a beteg nem vállalta. Ezt követően csökkenő dózisú PTU-kezelés mellett szakrendelésünkön ellenőriztük 2-3 havonta. Állapota 2013 októberében romlott, fáradékonnyá vált, hyperthyreosis progresszióját észleltük (TSH: 0,006 $\mathrm{mU} / 1, \mathrm{FT}_{4}$ : 67,89 $\left.\mathrm{pmol} / \mathrm{l} ; \mathrm{FT}_{3}: 31,92 \mathrm{pmol} / \mathrm{l}\right)$. Új tünetként lábdagadás jelentkezett, amely diuretikus kezelés ellenére fokozódott, lábfeje, bokája fájdalmassá vált. Éjszakai hőemelkedést tapasztalt, szájában aphthák jelentek meg, emiatt táplálkozni nehezen tudott. Az elvégzett kontroll nyaki ultrahang változatlan státuszt mutatott. A klinikai kép autoimmun betegség gyanúját vetette fel, ezért 2013 novemberében ez irányú kivizsgálásra és kezelés beállítására vettük fel immunológiai részlegünkre. Családi anamnézise szisztémás autoimmun betegség irányában negatív volt. Fizikális vizsgálattal testszerte livedo reticularis, szájnyálkahártyán aphthák, masszív alszároedema volt észlelhető. Laborleleteiből gyorsult süllyedés (We: $38 \mathrm{~mm} / \mathrm{h}$, normális tartomány: 3-12 mm/h), közepes fokú anaemia (hgb: $97 \mathrm{~g} / 1$, normális tartomány: 123$153 \mathrm{~g} / \mathrm{l}$ ), hypalbuminaemia (albumin: $28 \mathrm{~g} / \mathrm{l}$, normális tartomány: 33-50 g/1), mérsékelt azotaemia (GFR: 56 $\mathrm{ml} / \mathrm{min}$ ), iatrogen hypothyreosis (TSH: 5,57 $\mathrm{mU} / \mathrm{l}$ ), elevált CRP-érték $(76 \mathrm{mg} / 1$, normális tartomány $<7,5$ $\mathrm{mg} / \mathrm{l})$, csökkent komplementszintek voltak kiemelhetők $\left(\mathrm{C}_{3}: 0,66\right.$, normális tartomány: 0,8-1,5 g/1; $\mathrm{C}_{4}: 0,09$ $\mathrm{g} / \mathrm{l}$, normális tartomány: $0,2-0,5 \mathrm{~g} / \mathrm{l})$. A vizeletüledékben szemcsés és hialincilinderek mutatkoztak. Fokozott proteinuriát nem észleltünk (vizeletfehérje: $0,15 \mathrm{~g} / \mathrm{l}$ ). Az elvégzett hasi ultrahangvizsgálat a két vese vonatkozásában kóros eltérést nem mutatott, kevés kismedencei ascitest írt le. A klinikai kép akut glomerulonephritis mellett szólt. Az alkalmazott parenteralis, majd csökkenő dózisú oralis kortikoszteroidkezelés mellett oedemái fokozatosan kiürültek, közérzete lényegesen javult. Hypothyreosis miatt a PTU-t elhagytuk, a továbbiakban a szoptatás befejezését figyelembe véve tiamazolkezelés mellett döntöttünk (napi $10 \mathrm{mg}$ ). Időközben elkészült immunszerológiai vizsgálatok során ANCA-pozitivitás igazolódott (p-ANCA: 72,6 U/ml, c-ANCA: 104,4 U/ $\mathrm{ml}$, normális tartomány: 0,0-10,0 U/ml). A klinikai kép alapján ANCA-pozitív szisztémás vasculitis merült fel. 2013 decemberében nefrológiai szakvizsgálat során az akut nephritis teljes regresszióját véleményezték. Immunológiai gondozás során a kortikoszteroid dóziscsökkentése mellett panaszmentes maradt, ANCA-pozitivitása azonban perzisztált (PR3-ANCA: negatív; MPO-ANCA: $54,77 \mathrm{U} / \mathrm{ml}$ ). 2014 júniusában a metilprednizolont elhagyták, további kezelést nem javasoltak. Kis dózisú tiamazolkezelés (napi $10 \mathrm{mg}$ ) mellett euthyreoid állapotban volt tartható, majd ismételten manifeszt hyperthyreosis jelentkezett perzisztálóan jelentősen emelkedett TRAK-érték mellett (TSH: 0,005 mU/1; FT 4 : 37,49 pmol/1; $\mathrm{FT}_{3}$ : 10,85 pmol/1; TRAK: 37,42 IU/1), ezért a tiamazol dózisemelésére kényszerültünk (napi $20 \mathrm{mg}$ ). A kontroll nyaki ultrahang érdemben változatlan képet mutatott a kétoldali göbök progressziója, malignitásra utaló jel nélkül. 2015 márciusában a beteg sürgősséggel került ismét felvételre láz, torok-, végtagfájdalom, levertség miatt. Fizikális vizsgálattal soor mycosist, struma nodosát észleltünk. Laboratóriumi leleteiben gyorsult süllyedés (We: $65 \mathrm{~mm} / \mathrm{h}$ ), agranulocytosis (fehérvérsejtszám: 0,79 G/1, normális tartomány: 5,0-10,0 G/1; neutrophilszám: 0,013 G/I, normális tartomány: 2,0-7,0 $\mathrm{G} / \mathrm{l})$, emelkedett CRP-érték (154,8 $\mathrm{mg} / \mathrm{l})$, enyhe hyperthyreosis volt kiemelhető (TSH: $0,01 \mathrm{mU} / 1, \mathrm{FT}_{4}$ : $\left.21 \mathrm{pmol} / 1, \mathrm{FT}_{3}: 6,75 \mathrm{pmol} / \mathrm{l}\right)$.

Felvételét követően széles spektrumú antibiotikus (ceftazidim), antimycoticus (fluconazol) kezelést indítottunk kolóniastimuláló faktor adása mellett. Kezelésünk hatására leukopeniája megszűnt, tartósan láztalan- 
ná vált, közérzete javult. Hemokultúrából kórokozó nem tenyészett ki. Agranulocytosis hátterében tiamazolmellékhatás merült fel, ezért ezt elhagyva, napi $2 \times 500$ mg lítium-karbonát adását kezdtük vesefunkciós kontroll, szérumlítiumszint szoros ellenőrzése mellett. Mellékhatás nem jelentkezett. Hyperthyreosis, struma nodosa, illetve thyreostaticum mellett jelentkező agranulocytosisa miatt pajzsmirigybetegség definitív megoldása végett sebészeti konzíliumot kértünk, a beteget strumectomia céljából felvételre előjegyezték. Előkészítés után 2015 áprilisában kétoldali subtotalis pajzsmirigy-reszekciót végeztek. A posztoperatív szakban szövődmény nem lépett fel, a szövettan struma nodosát igazolt. A beteg hangképzése rendben volt. Mütét után egy hónappal érdemben panaszmentes volt, de a TSHkontroll manifeszt hypothyreosist jelzett (TSH: 31,54 $\left.\mathrm{mU} / 1 ; \mathrm{FT}_{4}: 10,11 \mathrm{pmol} / \mathrm{l} ; \mathrm{FT}_{3}: 4,06 \mathrm{pmol} / \mathrm{l}\right)$, ezért napi $50 \mu \mathrm{g}$ levotiroxinszubsztitúciót vezettünk be. A továbbiakban a beteg endokrinológiai gondozása félévente tervezett.

\section{Megbeszélés}

A Graves-Basedow-kór jó gyógyhajlamú, de recidívára hajlamos betegség, amely szülést követően nőkben gyakrabban manifesztálódik. A hyperthyreosis kezelésének első választandó gyógyszere a tiamazol, ez alól kivétel a szoptatás, illetve a terhesség első trimesztere. Utóbbi esetben PTU adandó, mivel a placentán, illetve a szoptatás során az anyatejbe kisebb koncentrációban jut át a hatóanyag a tiamazolhoz képest [1]. A hyperthyreosis miatt gondozott, szoptatás miatt PTU-val kezelt nőbetegnél állapotromlás, gyengeség, oedemakészség hátterében akut nephritis igazolódott, amelynek kóroki tényezőjeként az alapbetegség kezelésére alkalmazott PTU merült fel. Immunszerológiai vizsgálatok ANCA-pozitivitást mutattak, leletei alapján egyéb autoimmun betegség nem volt igazolható.

Ismert, hogy bizonyos gyógyszerek, mint antibiotikumok, thyreostaticumok, illetve pszichoaktív ágensek sporadikus esetekben kiválthatnak vasculitist $[3,4]$. A PTUindukált vasculitis főleg fiatal nőkben fordul elö, ami a pajzsmirigybetegségek magasabb prevalenciájával lehet összefüggésben [4]. ANCA-pozitivitást a PTU-val kezelteknél 15-64\%-ban észleltek, de csak 4-6,5\%-ban alakultak ki a vasculitis klinikai jelei [5]. A hosszú távú PTU-kezelés, illetve a hyperthyreosis relapsusa kockázati faktorként szerepel. A vasculitist kiváltó antigén alapján kétféle ANCA különböztethető meg: c- és p-ANCA. A p-ANCA perinukleárisan található és a célantigén gyakran a myeloperoxidáz, a c-ANCA esetén a proteináz-3 enzim [3]. Az ANCA-család autoantitestjei kötődnek a sejtek enzimantigénjeivel, és gyulladásos reakciót váltanak ki $[3,5,6]$. A betegség patogenezise nem egyértelmüen tisztázott. Feltételezések szerint a PTU interakcióba kerül a neutrophil granulocyták granulumaiban lévő MPO-val, a gyógyszerkötődést követően a megváltozott antigenitású MPO már képes aktiválni a T-lymphocytákat, és a granulumokból kiszabaduló enzimek előidézik az autoantitestek termelődését [4]. A betegeknél kiütés, láz, illetve glomerulonephritis, myalgia, arthritis, alveolaris haemorrhagia tünetei jelentkeznek [7, 8].

A leggyakrabban érintett szerv a vese. Egy japán tanulmányban 92 beteg vizsgálata alapján a renalis manifesztáció 38, a pulmonalis érintettség 19, míg a cutan megjelenés 13 százaléknak bizonyult [8]. Veseérintettség leginkább nephritis, illetve akut veseelégtelenség formájában jelentkezik, mivel a kiserek vasculitise általában nekrotizáló glomerulonephritissel jár. Enyhe formában a PTU elhagyása mellett a folyamat regrediál, de súlyosabb esetekben szteroid-, ciklofoszfamidkezelésre, esetleg plazmaferézisre is szükség lehet $[1,7,9-11]$. A vasculitis a PTU-kezelés megkezdését követően általában hetekkel később, más esetben hónapok, évek múlva alakul csak ki [4]. A potenciális immunogén stimulus megszüntetését követően a PTU-indukált vasculitis prognózisa jobb, mint a primer vasculitisek esetében. A kezelés felfüggesztését követően a vasculitis általában rendeződik, az ANCA-titer normalizálódik. A PTU szedése mellett a rutinszerü ANCA-meghatározást nem javasolják, mivel a vasculitis előfordulása ritka, illetve önmagában az ANCA-pozitivitás nem feltétlenül jár a vasculitis klinikai tüneteinek megjelenésével $[4,9]$. Az antitest-pozitivitás egyes esetekben még évekig perzisztálhat $[4,8,9,12]$.

Esetünkben a propiltiouracil elhagyása, illetve metilprednizolonkezelés mellett a folyamat regressziót mutatott, a beteg panasz- és tünetmentessé vált. Tiamazolterápiára tértünk át, majd közel másfél éves kezelést követően lázzal járó agranulocytosis miatt került sor a beteg ismételt osztályos felvételére. Ez a mellékhatás jellemzően a kezelés második-harmadik hónapjában alakul ki [1]. Ha a leukocytaszám csökkenő tendenciát mutat, gyakoribb vérképellenőrzés szükséges. Amennyiben a kvalitatív vérképben a neutrofilszám $40 \%$ alá csökken, a kezelés megszakítandó. Kolóniastimuláló faktor adása nélkül az agranulocytosis spontán megszúnése 9-10 nap alatt várható.

Esetismertetésünkkel a hyperthyreosis kezelési nehézségeire szeretnénk felhívni a figyelmet. Az esetet egyrészt a szövődményként kialakult kórképek ritka előfordulása, másrészt a kedvező terápiás válasz miatt tartottuk közlésre érdemesnek.

Anyagi támogatás: A közlemény megírása anyagi támogatásban nem részesült.

Szerzôi munkamegosztás: A kézirat megszövegezésében S. G. előkészítő munkáját követően, a társszerzők egyenlő arányban vettek részt. A kézirat végleges változatát valamennyi szerző elolvasta és jóváhagyta.

Érdekeltség: A szerzőknek nincsenek érdekeltségeik. 


\section{Irodalom}

[1] Leövey, A., Nagy, V. E., Paragh, Gy., et al.: Clinical practice handbook of endocrinology and metabolism. [Az endokrin és anyagcsere-betegségek gyakorlati kézikönyve.] Medicina Könyvkiadó, Budapest, 2011. [Hungarian]

[2] Khanolkar, M. P., Owen, P. J., Lazarus, J. H.: Propylthiouracil induced ANCA positive vasculitis: A case report. Int. J. Endocrinol. Metab., 2004, 2(1), 47-50.

[3] Tulassay, Zs.: Basics of internal medicine. [A belgyógyászat alapjai.] Medicina Könyvkiadó, Budapest, 2007. [Hungarian]

[4] Silva, S. V., Ferreira, J. P., Carvalho, S., et al.: Antineutrophil cytoplasmatic antibody positive systemic vasculitis in a patient treated with propylthiouracil. Acta Reumatol. Port., 2013, 38(4), 302-305.

[5] Chen, Y., Bao, H., Liu, Z., et al.: Clinico-pathological features and outcomes of patients with propylthiouracil-associated ANCA vasculitis with renal involvement. J. Nephrol., 2014, 27(2), 159164.

[6] Tetikkurt, C., Yuruyen, M., Tetikkurt, S., et al.: Propylthiouracilinduced lupus-like or vasculitis syndrome. Multidiscipl. Resp. Med., 2012, 7(1), 1.

[7] Dolman, K. M., Gans, R. O., Vervaat, T. J., et al.: Vasculitis and antineutrophil cytoplasmic autoantibodies associated with prophylthiouracil therapy. Lancet, 1993, 342(8872), 651-652.
[8] Gao, ., Zhao, M. H.: Review article: Drug-induced anti-neutrophil cytoplasmic antibody-associated vasculitis. Nephrology (Carlton), 2009, 14(1), 33-41.

[9] D'Cruz, D., Chesser, A. M., Lightowler, C., et al.: Antineutrophil cytoplasmic antibody-positive crescentic glomerulonephritis associated with anti-thyroid drug treatment. Br. J. Rheumatol., 1995, 34(11), 1090-1091.

[10] Pillinger, M., Staud, R.: Wegener's granulomatosis in a patient receiving propylthiouracil for Graves disease. Semin. Arthritis Rheum., 1998, 28(2), 124-129.

[11] Gunton, J. E., Stiel, J., Caterson, R. J., et al.: Anti-thyroid drugs and antineutrophil cytoplasmic antibody positive vasculitis. A case report and review of the literature. J. Clin. Endocrinol. Metab., 1999, 84(1), 13-16.

[12] Harper, L., Cockwell, P., Savage, C. O.: Case of propylthiouracilinduced ANCA associated small vessel vasculitis. Nephrol. Dial. Transplant., 1998, 13(2), 455-458.

(Sohár Gábor dr., e-mail: gabor.sohar@gmail.com)

\section{A rendezvények és kongresszusok híranyagának leadása}

a lap megjelenése előtt legalább 40 nappal lehetséges, a 6 hetes nyomdai átfutás miatt. Kérjük megrendelőink szíves megértését.

A híranyagokat a következő címre kérjük: Orvosi Hetilap titkársága: Budai.Edit@akkrt.hu Akadémiai Kiadó Zrt. 